\title{
PENDIDIKAN ISLAM MULTIKULTURAL DI PONDOK PESANTREN ULUMUL QUR'AN STABAT KAB. LANGKAT
}

\author{
Siti Nurhaliza, Ihsan Sufika Siregar \\ Universitas Islam Negeri Sumatera Utara Medan \\ E-mail: sitinurhalizaa317@gmail.com,ihsansufika234@gmail.com
}

How to Cite:

Nurhaliza, S., \& Siregar, I. S. (2020). Pendidikan Islam Multikultural di Pondok Pesantren Ulumul Qur'an Stabat Kab. Langkat. Fitrah: Journal of Islamic Education, 1(1). 89-106,

\section{ARTICLE HISTORY \\ Received :05 July 2020 \\ Revised :13 July 2020 \\ Accepted :20 July 2020 \\ Published :25 July 2020}

\section{KEYWORDS:}

Pesantren, Islamic

Education, Multicultural

\section{ABSTRACT}

Multiculturalism is a culture or perspective and lifestyle in society. Where in there are various cultural differences, race, religion, gender, ethnicity, language and others. This research is supported by students who have multiculturalism studies. Which is a tribe, suk and culture. Therefore multiculturalism education in the ulumul Qur'an Islamic boarding school in Langkdat is able to provide and carry out multiculturalism education in it which is not in accordance with one another. With the aim of building peace with one another. And to get to know each other the various cultures of each individual, also the creation of good communication between one another. This research is a study using historical research methods and research through one of the alumni of the pesantren Ulumul Qur'an. the results or research findings are the ulumul qura'an pesantren has carried out the multicultural education process. This multicultural education includes the boarding school curriculum implicitly. This in no way distinguishes between students with one another with a variety of cultures that have.

\section{ARTICLE HISTORY \\ Diterima :05 July 2020 \\ Direvisi : :13 July 2020 \\ Disetujui :20 July 2020 \\ Diterbitkan :25 July 2020}

\section{KATA KUNCI:}

Pesantren, Pendidikan Islam, Multikultural

\begin{abstract}
ABSTRAK
Multikultural merupakan suatu budaya atau cara pandang dan gaya hidup dalam bermasyarakat. Dimana didalmnya terdapat berbagai perbedaan budaya, ras, agama, jenis kelamin suku, bahasa dan lainnya Penelitian ini dilatarbelakangi oleh permasalahan sosial yang sering terjadi akibat perbedaan kultur antar santri, baik dari segi etnis, suku dan budaya.. Maka dari itu pendidikan multikulturalisme di pondok pesantren ulumul qur'an yang berada di Stabat kabupaten Langkat ini mampu memberikan dan mengadakan pendididikan multikulturalisme didalamnya yang tidak membedakan anatara yang satu dengan yang lain. Dengan tujuan untuk membangun sikap perdamaian anatara yang satu dengan yang lainnya. Dan untuk saling mengenal berbagai budaya dari masing-masing individu, juga terciptanya suatu komunikasi yang baik antara yang satu dengan yang lainnya. Penelitian ini merupakan penelitian dengan menggunakan metode penelitian historis dan melalui wawancara dari beberapa santri dan alumni santri ulumul qur'an Stabat Kab. Langkat. Hasil atau temuan penelitiannya adalah bahwa pesantren ulumul qura'an ini telah menjalankan suatu proses pendidikan multikultural tersebut. Bahkan pendidikan multikultural ini telah masuk didalam kurikulum pondok pesantren secara tersirat. Yang didalamnya tidak membeda-bedakan antara santri yang satu dengan santri yang lainnya dengan berbagai budaya yang dimilikinya.
\end{abstract}




\section{PENDAHULUAN}

Indonesia adalah negara yang kaya budaya didalamnya terdapat banyak suku, ras, agama dan bahasa. Kekayaan tersebut seharusnya menjadi suatu acuan untuk saling mengenal, dan dalam arti yang lebih luas dan harus saling pengertian ditengah perbedaan. Kekayaan multikultural yang dimiliki Indonesia disatu sisi adala anugrah tetapi disisi lain juga bisa menjadi suatu masalah. Sebab persoalan yang kita hadapi memang kompleks dan beragam, karena itu keberagaman budaya memerlukan perekat agar terhindar dari perpecahan, tanpa mampu menghadirkan perekat yang menyatukan itu, bibit-bibit perpecahan akan tumbuh tak terkendali. (Dani Nurcholis, 2019)

Multikultural adalah sebuah kenyataan dimana penduduk dunia semakin berkembang dan semakin melebur, yang dapat berdampak terhadap perubahanperubahan besar terhadap system pemerintahan, dunia pedindidikan dan perekonomian yang telah matang untuk dapat berubah menjadi sesuatu yang lebih baik. Penduduk dunia tentunya hidup didalam masyarakat yang penuh dengan kedekatan dan berinteraksi dan saling berkomunikasi dengan sebagian individu yang mempunyai keragaman budaya dari masing-maisng individu. Maka dari itu setiap manusia pasti terlahir berbeda-beda dengan berabagai ragam keunikan, kelebihan dan kekurangannya bagi masing-masing individu.
Namun dengan adanya perbedaan ini, baik dalam budaya, perbedaan suku, ras, sumber daya, dan harapan ini pula yang menimbulkan permasalahan dan terjadinya konflik social. Dan bahkan ketika adanya perbedaan agama, posisi social dan perekonomian secara bersamaan maka semakin besar kesempatan terjadinya permasalahan yang menyebabkan perpecahan antara yang satu dengan yang lain. Multikultularisme adalah istilah yang samar, ambivalen dan debatable. Namun disisi lain kebudayaan-kebudayaan yang Beragam tersebut tidak hannya menjadi masalah atau membuat perpecahan, namun kebudayaan-kebudayaan ini juga mengandung kebaikan yang dapat diambil hikmah dan pelajaran dari budaya mereka lainnya. Multikulturalisme adalah sebagai inveratif peradaban dalam arti isu yang terus "memprovokasi" keingin tahuan sekaligus juga mengandung opini mengenai keberhasilan harapan-harapan yang disandarkan kepadanya. Multikultularisme adalah asumsi yang mengandung bahwa setiap kebudayaan yang kita miliki mempunyai kedudukan dan posisi yang setara dengan kebudayaan orang lain serta mempunya nilai-nilai didalamnya, sehingga setiap kebudayaan yang beragam akan berhak mendapatkan posisi yang layak dan posisi yang setara sebagaimana kebudayaan lainnya.(Zakiyuddin Baldhawi, 2005) 
Pondok pesantren merupakan salah satu tempat pembelajaran dimana tempat tersebut menjadi pusat pengajaran agama Islam yang sangat berperan penting dalam mengembangkan dan menciptakan suatu persatuan yang utuh terhadap persatuan bangsa. pondok pesantren inilah yang menjadi tempat pembelajaran yang menekankan tentang pemahaman agama ruh bagi setiap umat manusia, yang dapat menciptakan dan mengembangkan bakatbakat serta potensi yang dimilikinya menjadi potensi yang yang luar biasa yang dapat diciptakan oleh santri-santri yang ada dipondok pesantren. Menurut Kementrian Agama, terdapat pesantren yang telah tersebar luas diseluruh wilayah Indonesia, kira-kira sekitar 27 ribu lebih pesantren yang ada di Indoneisa saat ini. (Abdullah, 2018)

Pada dasarnya ketika pondok pesantren berdiri di suatu tempat yang memiliki corak sosial budaya dalam Pengamalan aqidah, ibadah dan muamalah di dalam kehidupan pada daerah tersebut, maka pondok pesantren itu menjadi catatan sejarah tersendiri dalam melewati dinamika kehidupan sosial dan budaya yang ada di dalam kehidupan bermasyarakat, oleh sebab itu pesantren itu berdiri. Mayoritas pondok pesantren itu lahir di berbagai tempat khusus di nusantara ini atau di negara kita, bahwa pondok pesantren yang berhasil mengakulturasikan yang berhasil mengikuti dinamika kehidupan sosial yang beragam, maka pondok pesantren itu akan bertahan dengan kuatnya gempuran keberagaman dan memberikan corak atau warna tersendiri dalam perubahan sosial dan kebudayaan yang baik. Ada beberapa ciri khas nilai-nilai yang telah menjadi tradisi dalam pesantren tersebut yaitu kesederhanaan, keikhlasan, kemandirian, kesabaran, kedisiplinan dan ukhuwah islamiah. Didalam pesantren itulah terbentuknya ciri khas nilai-nilai yang memberikan makna untuk mejadi yang lebih baik. Bahkan Tidak hannya nilai-nilai yang terkenal tersebut yang dapat diciptakan dipondok pesantren, namun masih banyak nilai-nilai agama yang dapat dibentuk dalam kepribadian manusia yang berkualitas. Yang insyaAllah nantinya akan berguna bagi kehidupan bangsa dan Negara.

Dalam penelitian ini peneliti akan melakukan penelitian yang dilakukan dipondok pesantren Ulumul Qur'an yang terletak di kec. Stabat Kab. Langkat sumatera utara. Oleh karena itu focus pada penelitian ini mengarah pada santri-santri yang memilii latar belakang budaya dan suku yang berbeda-beda. Masalah dalam penelitian ini hannya saja masih ada santri yang kurang berpartisipasi dalam membantu penelitian ini, karena aktifitas mereka selalu disibukkan dengan menghafal ayat-ayat AlQur'an. Maka dari itu pihak pondok pesantren mengambil keputusan untuk menjadikan penidikan multikultural ini sebagai kurikulum yang ada dipondok 
pesantren tersebut. Maka dari itu penelitian ini sangat penting sekali dilakukan untuk mengetahui keanekaragaman yang berbedabeda yang dimiliki oleh setiap individu. Yang dapat dijadikan suatu pelajaran bagi individu lain dan memberkan pengetahuan akan adanya keanekaragaman budaya yang berbeda.

Didalam pondok pesantren Ulumul Qur'an Stabat Kab. Langkat ini tentunya memiliki santri-santri yang berasal dari daerah lain memilik latar belakang etnis yang berbeda-beda. Maka dari itu didalam pondok pesantren tersebut memiliki pendidikan multikultural bahkan mempelajari pendidikan islam multikultural karena telah dijadikan sebagai kurikulum pemdidikan pondok pesantren tersebut.

Multikulturalisme adalah sebuah persepsi ataupun cara pandang dan gaya hidup dalam masyarakat, secara gagasan konstektual bahwa multikulturalisme ini menolak segala bentuk rasisme. Oleh karena nya konsep multikulturalisme ialah mengafirmasi segala pluralitas, yakni tidak membedakan agama, etnis, budaya, suku dan bahasa. Konsep dan realitas multikulturalisme di dalam kehidupan masyarakat global yang sekarang ialah sangat penting untuk menghadapi perbedaan, prinsip dasar dan nilai yang terkandung dalam kehidupan keberagaman yang terbalut dalam konsep multikulturalisme adalah prinsip keadilan, kesetaraan, keterbukaan dan pengakuan terhadap keberagaman itu sendiri.

Maka itu konsep multikulturalisme ini telah menjadi budaya dan living reality dari nenek moyang dan kehidupan bangsa ini. Kita harus mengintegrasikan sebagai pondasi moral di kehidupan yakni dalam pendidikan. Di dalam pendidikan yang tidak mengedapakan pluralitas, akan berakibat munculnya segala bentuk pertentangan ekstrem pemikiran dalam dunia pendidikan. Bagaimana pada zaman dahulu tonggak pendidikan yang dibangun oleh para wali atau sunan di nusantara adalah corak pola pendidikan pondok pesantren, yang pada dasarnya bahwa sejatinya ajaran Islam adalah ajaran yang toleransi dan mengajarkan dasar pluralitas secara mendalam, baik dari aspek sosial, budaya, ekonomi dan yang lainnya.

Mengenai beberapa pondok pesantren yang berdiri di tanah majemuk di Sumatera Utara sebagai miniatur bangsa Indonesia dan khususnya di kabupaten Langkat yang yang tidak bisa dikatakan mayoritas atau tidak dalam kehidupan berbudaya, kemajemukan dari beberapa perbedaan yang ada. Tepatnya di pondok pesantren Ulumul Quran yang setiap pesantren memiliki corak khas dari pendidikan yang diutamakan di dalam menciptakan agent of excellent atau pengkaderan dari santri-santri yang nantinya akan di hasilkan dari pondok pesantren itu, dan corak utama pendidikan yang didapatkan dalam pondok pesantren Ulumul 
Quran Kecamatan Stabat Kabupaten Langkat adalah bagaimana memiliki santri yang mempunyai pengetahuan teori serta praktek dalam pemahaman dan pengetahuan secara mendalam pada Alquran dan menciptakan hafizh dan Hafidzah, yang memiliki program tersendiri dan program terunggulkan di dalam pesantren ini.

Dipondok pesantren uluml qur'an yang berada di kec.Stabat kabupaten Langkat ini merupakan salah satu tempat aktivitas pembelajaran Islam yang didirikan untuk mewujudkan suatu perdamaian yang rukun dan dapat memberikan pengetahuan yang lebih luas tentang cakrawala keilmuan, pemikiran, pemahaman dan penglaman uma Islam. Dengan adanya Lembaga pendidikan islam ini diharapkan dapat mewujudkan citacita dan harapan umat Islam yang dapat mencetak genarasi terbaik umat Islam, terkhusus umat Islam di kab.Langkat yang berkualitas. Sehingga kab.Langkat mempunyai pemuda yang menjadi generasigenarasi Islam yang mampu merubah menjadi yang lebih baik untuk kedepannya.

Maka dari itu multicultural ini merupakan sesuatu yang sering terjadi dan banyak dipermasalahkan oleh banyak orang, bukan hannya dipondok pesantren namun diberbagai lembaga juga sering diperbincangkan. Sehingga pembahasan ini sangat menarik sekali untuk penulis yang akan membahas pembahasan ini.
Berdasarkan permasalahan diatas, maka penulis tertarik untuk melakukan suatu penelitian tentang pendidikan Islam multikultural di pesantren Ulumul Qur'an Stabat Labupaten Langkat.

\section{KAJIAN TEORI}

\section{Pendidikan Islam}

Pendidikan berasal dari istilah pedagogi. Yang berasala dari bahasa Yunani Kuno paidos dan agoo. Dimana Paidos adalah "budak" dan agoo adalah "membimbing". Jadi, pedagogie diartikan sebagai " sesorang yang dapat membimbing untuk belajar". Maka dari itu pedagogie ini dimaksudkan sebagai "ilmu mendidik". Dimana sesorang dapat membimbing secara sadar dan mejadikan anak didik dapat mengembangkan kemampuan bakat dan potensi yang dimilkinya. Menurut Darmaningtyas pendidikan adalah suatu usaha yang sistematis yang dilakukan secara sengaja untuk mengembangkan potensi dan bakat yang dimiliki peserta didik untuk mencapai taraf kemjuan dan kehidupan yang lebih berkualitas.(Darmaningtyas, 2004) sedangkan Pendidikan Islam merupakan sebuah upaya untuk mengembangkan potensi, mendukung dan mengajak setiap umat dalam hal-hal yang lebih bermakna dengan berlandaskan ajaran-ajaran Islam yang berkualitas dan kepribadian yang mulia sehingga terbentuknya pribadi muslim yang lebih sempurna dan berakhlakul karimah. 
Jadi pendidikan Islam dalam jurnal ini adalah suatu system pendidikan yang berlandaskan dan lebih mengedepankan nilai-nilai ajaran Islam yang didalamnya mencakup seluruh aspek kehidupan yang berkaitan dengan manusia. yang dapat menjamin kebahagiaan yang tidak hannya didunia saja namun juga diakhirat. Dengan Sistem kependidikan Islam inilah manusia dapat memahami dan mengembangkan kemampuannya dengan berlandaskan ajaran Islam yakni Al-Qur'an dan Hadits yang diwujudkan dalam bentuk pemikiran dan teori-teori pendidikan. (Rois, 2013)

Menurut Hery Nor Aly dan Mundir Suparta, tujuan pendidikan Islam terbagi menjadi dua yakni tujuan umum dan tujuan khusus. Tujuan umum pendidikan Islam adalah untuk mendidik individu mukmin menjadi manusia yang terdidik agar patuh, dapat bertaqwa dan beribadah dengan baik terhadap perintah Allah Swt. Sehingga mendapatkan kebahagiaan.

Kemudian tujuan khusus dari pendidikan Islam adalah

a. Untuk Mendidik manusia yang sholeh, berakhlak mulia yang berkaitan dengan perkembanganya, emosional dan intelektual.

b. Menjadikan individu yang soleh di semua lingkungan, baik lingkungan keluarga maupum lingkungan masayarakat yang muslim.

c. Mendidik manusia yang saleh yang berguna bagi keluarga, masyarakat, bangsa hingga Negara.

Kemudian menurut Achmadi tujuan dibagi menjadi tiga bagian yaitu Tujuan tertinggi adalah tujuan yang bersifat pasti dan mutlak yang tidak mengalami perubahan karena berlandaskan dengan Al-Qur'an dan Hdist yang didalamnya mengandung kebenaran yang haqiqi dan universal. Dalam hal ini Tujuan tertinggi Pendidikan Islam sesuai pada tujuan hidup manusia dan sesuai peranannya sebagi hamba Allah Swt. yaitu:

a. Menjadi ciptaan Allah yang mengerjakan segala perintahnya-Nya dan menjauhi larangan-Nya.

b. Menjadikan peserta didik menjadi kahalifah dimuka bumi ini yang mampu menjaga dan melestarikan alam raya ini.

c. Meraih kebahagiaan dan kesejahteraan baik didunia maupun di akhirat.

Kemudian berbeda dengan tujuan tertinggi, tujuan umum Pendidikan Islam lebih bersifat realistik dan empiris, yang berfungsi sebagai arah untuk perubahan sikap, perilaku, tingkah laku dan kepribadian individu, sehingga dapat menciptakan dirinya menjadi manusia yang insan kamil. Sedangkan tujuan operasional adalah suatu pengkhususan diantara tujuan tertinggi dan tujuan umum. Dimana Tujuan ini bersifat relatif, dimana tujuan operasional ini dapat memungkinkan untuk 
melakukan suatu perubahan yang sesuai dengan kebutuhan atas dasar tujuan tertinggi dan tujuan umum.

Pengkhususan tersebut berlandaskan pada tiga hal, yaitu:

a. Kultural dan harapan bangsa dimana pendidikan Islam itu dilaksanakan.

b. Seluruh potensi peserta didik.

c. Tuntutan situasi, dan keadaan pada kurun waktutertentu

Dari penjelasan diatas maka dapat diambil sebuah kesimpulan bahwa tujuan pendidikan Islam ialah menjadikan manusia yang insan kamil yang sesuai dengan fitrahnya untuk mendekatkan diri kepada Allah Swt dan sebagai khalifah dimuka bumi ini yang dapat memakmurkan alam raya ini. Tidak hannya untuk mendekatkan diri kepada Allah saja manusia yang baik juga dituntut harus mampu menerima realitas kehidupan dengan menjaga dan menebarkan cinta dan kasih saying terhadap seluruh alam semesta ini.

Output pendidikan islam adalah seseorang yang tidak hannya memiliki pribadi yang sholeh secra individu tetapi juga memiliki keshalehan dalam social keadilan, persmaan, perdamaian dan kemanusiaan yang tercermin dalam konsep rahmatallil'alamin yang merupakan sesuatu yang penting yang harus dicapai pendidikan Islam.(Mustaghfiroh et al., 2013)

\section{Pendidikan Multikulturalisme}

Multikulturalisme adalah sebuah persepsi ataupun cara pandang dan gaya hidup dalam masyarakat, secara gagasan konstektual bahwa multikulturalisme ini menolak segala bentuk rasisme. Oleh karena nya konsep multikulturalisme ialah mengafirmasi segala pluralitas, yakni tidak membedakan agama, etnis, budaya, suku dan bahasa. Konsep dan realitas multikulturalisme di dalam kehidupan masyarakat global yang sekarang ialah sangat penting untuk menghadapi perbedaan, prinsip dasar dan nilai yang terkandung dalam kehidupan keberagaman yang terbalut dalam konsep multikulturalisme adalah prinsip keadilan, kesetaraan, keterbukaan dan pengakuan terhadap keberagaman itu sendiri. Menurut Sonia Nieto, pendidikan multikultural adalah suatu proses pendidikan yang berwawasan luas dan mendasar bagi seluruh manusia. Jenis pendidikan ini tidak menentang adanya kehidupan pluralitas (etnik, ras, bahasa, agama, ekonomi, gender dan lain sebagainya) yang dapat diimplementasikan pada peserta didik, komunitas mereka dan guru-guru. Menurutnya pendidikan multikultural ini harus melekat dalam kurikulum pendidikan dan strategi pengajaran, dan dalam komunikasi yang dilakukan peserta didik, guru dan keluarga serta yang bersangkutan dengan suasana kegiatan pembelajaran (Sonia Nieto, 2002) 
Pendidikan multicultural lahir karena banyaknya permasalahan manusia yang ditindas akibat adanya perbedaan anatar yang satu dengan yang lain. Padahal pendidikan multikultural ini sangat penting bagi manusia, karena manusia diciptakan semuanya dengan setara, dapat bekerja sama, saling membantu, menghargai dan menghormati walaupun berbeda-beda dari segi etnis, ras, budaya, jenis kelamin, agama dan cara pandang. (Murniati Agustian, 2019) Secara historis, pendidikan multikultural ini timbul pada lembaga pendidikan di Amerika yang mulanya terdapat deskriminasi etnis, tetapi lama kelamaan mendapatkan perhatian khusus yang diberikan oleh pemerintah. Pendidikan multikultural ini sendiri menjadikan latar belakang budaya peserta didik menjadi Bergam macam yang dapat digunakan untuk meningkatkan dan mengembangkan kualitas pembelajaran peserta didik baik dikelas mapun dilingkungan sekolah. Maka dari itu pendidikan multikultural ini dirancang dengan sebaik mungkin untuk memperluas konsep-konsep perbedaan budaya, kesamaan yang berprinsip pada demokrasi, keadilan dan kesetaraan, beroroentasi pada kemanusiaan, kebersamaan, kesetaraan dan kedamaian serta mau menerima dan menghargai keragaman dengan berlandaskan Al-Qur'an dan Hadist. Karena didalam AlQur'an sendiri sudah memberitahukan dan bahwa manusia memang diciptakan dengan berbeda-beda dan beragam. Agar kita saling mengenal. Hal ini ditegaskan dalam QS. alHujurat:13 Artinya: "Hai Manusia, sesungguhnya Kami ciptakan kamu dari seorang laki-laki dan seorang perempuan dan menjadikan kamu berbangsa-bangsa dan bersuku-suku supaya kamu saling mengenal.”. penekanan dari multikulturalisme ini adalah pada kesetaraan budaya. Dimana setiap perbedaan budaya semuanya setara. Dengan adanya Perkelahian, dan kakacauan yang terjadi maka muncullah kelompok yang mengganggap bahwa budayanyalah yang paling sempurna dibandingkan dengan budaya lain. Ini merupaka suatu pengabaian terhadap adanya keragaman dalam dunia pendidikan. (Rois, 2013)

Secara etimologis multikulturalisme berasal dari kata multi (banyak), kultur (budaya), dan isme (aliran/paham). Maka multikulturalisme adalah sebuah aliran yang menerima adanya budaya yang banyak atau beragam. Secara hakiki, hal itu terkandung pengakuan akan martabat manusia yang hidup dalam keragaman budaya yang unik yang dimiliki oleh masing-masing individu. Secara sederhana multikulturalisme adalah sebuah paham yang mengakui adanya perbedaan kultur yang terjadi akibat adanya keragaman budaya dan keragaman lainnya. Sehingga dasar dari munculnya multikulturalisme berawal dari studi aatas kebudyaan. Dari jaran tersebut semoga 
dapat memunculkan semangat menghormati dan menghargai terhadap perbedaanperbedaan yang dapat melahirkan perilku yang menrima perbedaan dalam kehidupan ditengah masyarakat yang beranekaragam budaya. Dalam multicultural dituntut adanya kebijaksanaan dalam melihat perbedaan budaya tersebut sebagai sutau kenyataan dalam berkehidupan bermasyarakat dan bernegara. Kebijaksanaan tersebut tercipta apabila seseorang mau menerima dan menjalani kehidupan bersama dengan berbagai realitas budaya yang beragam yang sudah menjadi kodrat, dalam kehidupan pribadi maupun kehidupan masyarakat.

Multikulturalisme ini sebenarya tidaklah datang sekaligus secara langsung Sebagai suatu kebijaksanaan, tetapi multikulturalisme merupakan hasil dari proses pencapaian intelektual yang panjang. Kemudian telah muncul suatu pemecahan konflik horizontal yang mengacaukan bangsa indonesia dewasa ini dari sudut kebudayaan, bukan melalui cara-cara kekerasan ataupun cara-cara lain yang tidak sesuai dengan kondisi bangsa Indonesia yang beragam(Goyena \& Fallis, 2019)

\section{Multikultural Dalam Perspektif Islam}

multikultural merupakan suatu paradigma yang memandang realitas multikultural bukan sebagai problem melainkan sebagai asset. Dalam perspektif islam keragaman tersebut justru merupakan sunnatullah atau kehendak tuhan yang dijelaskan dalam
alQur'an QS Hud ayat 118 dan Arrum ayat 22, yang sengaja diciptakan sebagai sarana saling mengenal anatar yang satu dengan yang lain yang tercantum dalam QS AlHujurat ayat 13. Dengan demikian Islam secara tegas menghendaki dan menganggap realitas multikultural bukan sebagai problem melainkan sebagai asset yang bisa didayagunakan baik dalam konteks hubungan social maupun dalam relasi kemanusiaan yang lebih luas. Sebagai capital multikultural ada empat dasar yang bisa menjadi pijakan utama

a. Multikultural sebagai sarana saling mengenal

Kata lita'arafu menunjukkan sati konsep bahwa keragaman suku-suku dan bangsa bukan sebagai masalah, melainkan sebagai upaya untuk saling mengenal, saling berukhwah islamiyah dan saling bekerja sama serta menunjukkan adanya interaksi komunikasi antara yang satu dengan yang lain.

b. Keyakinan dan kepercayaan kaum muslimin, akan kemuliaan dalam menghormati pribadi setiap manusia yang berbeda agama, ras dan warna kulitnya.

Dasar ini menunjukkan bahwa keragaman diantara manusia memiliki garis genetis dan genealogis yang sama sebagai bani adam dan kerenanya mereka memiliki 
kedudukan yang sama-sama mulia sebagai manusia.

c. Keragaman merupakan ayatullah (tanda-tanda kebesaran Allah)

Dasar ini memiliki tingkat yang lebih tinggi bahwa keragaman bukan sekedar hiasan dunia, melainkan sebagai manifestasi dari kebesaran Allah Swt. Bahkan keragaman bisa saja melahirkan capital spiritual seseorang jika ia mampu menangkapnya sebagai sinyal kebutuhan, karena didalamnya penuh dengan perenunganperenungan ilahi. Merenungkan tanda-tanda kebesaran Allah melalui berbagai realitas multikultural yang ada akan melahirkan ketakjuban dan semakin memperkuat keyakinan seseorang.

d. Kergaman merupakan kehendak Allah Swt. Yang tercantum dalam QS Hud ayat $118-119$

Ayat tersebut memberikan penegasan bahwa keragaman bukan sekedar proses historis manusia melainkan juga telah menjadi kehendak tuhan. Tuhan bisa saja menghendaki umat menjadi satu, melainkan tuhan menghendaki adanya keragaman. (Sauqi Futaki, 2019)

Adapun pendidikan Islam berwawasan multikultural yang menerima adanya keragaman budaya tercantum dalam Q.S Hud ayat 11, didalamnya menegasakan bahwa Allah menjadikan manusia sebagai umat yang bergam. Kemudian dalam Q.S alHujurat ayat 13 yang mengajarkan kita untuk saling mengenal dari berbagai keragaman suku, bangsa, warna kulit, bahasa, agama dan lain-lain. Kemudian dalam Q.S Ali Imran ayat 64 dan yunus ayat 7 dimana ayat tersebut menjelaskan harus menerima adanya suatu perbedaan dan keragaman yang bernilai positif. Kemudian Q.S. AlHujurat ayat 15. Bahwa perbedaan tidak perlu dipermasalahkan dalam hidup, tetapi harus dipergunakan dalam berubuat kebaikan dan dapat menegakkan perdamaian. Maka dari itu perbedaan tersebut harus diakui sebagai sunnatullah, yang sudah diatur sesuai porsinya tanpa menghilangkan perbedaan-perbedaan yang ada dalam kehidupan masyarakat dan Negara. begitulah indahnya pendidikan Islam sehingga Badri Khaeruman mengatakan "bahwa Islam sebagai pembawa rahmat bukan sebagai laknat". Maka dari itu setiap manusia harus mengupayakan adanya suatu keragaman dalam budaya yang ada dengan tidak adanya perpecahan yang menyebebkan permusuhan. Begitu juga sebagaimana disampaikan oleh Mulyasa bahwa setiap manusia harus salaing menghormati dan menghargai kebudayaan lain dalam social bermasyaraka.(Badri Khairuman, 2004) 
Aspek-Aspek Konsep Pendidikan Islam Multikultural

a. Pendidikan Islam multikultural adalah pendidikan yang menerima dan menghargai segala bentuk keragaman yang berbeda-beda. Dan mampu menyikapi keragaman tersebut dengan bijaksana.

b. Pendidikan Islam multikultural merupakan pendidikan yang dilakukan secara sadar secara sisitematis untuk membangun rasa kesadaran diri, pengertian, dan pemahan individu terhadap kehidupan yang nyata pada pluralismultikultural. Karena hal ini sangat penting untuk dilaksanakan, karena jika tidak adanya usaha sadar yang secara sistematis, maka realitas keragaman akan memunculkan sikap eksklusivitas yang menantang. Bahkan akan menimbulkan sikap untuk melakukan penguasaan terhadap mereka yang memiliki perbedaan. Sehingga timbul rasa ambisius yang tinggi untuk menakhlukkan mereka yang beragam

c. Didalam pendidikan Islam multikultural tidak adanya paksaan dan penolakan terhadap anak didik yang mempunyai keragaman suku, agama, ras, atau golongan. Masingmasing yang beragam perbedaan harus diperlakukan dengan sama dan diposisikan secara setara, karena setiap individu semuanya sama tidak adanya perbedaan diantara mereka. Maka dari itu tidak ada yang lebih teratas anatara yang satu dengan yang lainnya. Maka dari itu masingmasing harus diperlakukan dengan sama.

d. pendidikan Islam multikultural memberikan peluang untuk dapat berkreasi dan berkembangnya rasa percaya diri kepada setiap peserta didik. Karena hal ini dibangun untuk meenumbuhkan rasa kepercyaan diri peserta didik terutama bagi peserta didik dari kalangan orang yang kurang berkecukupan atau kelompok yang relative terisolasi. (Abdullah, 2018)

Tujuan dari pendidikan multikultural adalah mewujudkan suasana yang kondusif terhadap masyarakata yang beragam, menumbuhkan rasa kesadaran anak terhadap budaya mereka sendiri dan dapat menyelaraskan bahwa tidak ada hannya ada satu acara hidup tetapi ada bnayak cara hidup yang lebih beragam, menumbuhkan terhadap gaya hidup lain selain gaya hidup mereka sendiri sehingga mereka saling menghargai adanya perbedaan, dan menjadikan anak tersebut dapat mengembangkan dan mengimplementasikan kultur sejarah mereka sendiri.(Samsul Mu'arif, 2005). Pendidikan multikultural 
idealnya bertujuan untuk mempromosikan tentang kesadaran kultural, memberikan peluang untuk belajar dalam memahami perbedaan bagi semua individu dan kelompok masyarakat, mempromosikan identias diri sekaligus mendorong terwujudnya kesatuan melalui keragaman tersebut. (Zakiyuddin Baldhawi, 2005)

\section{METODE PENELITIAN}

Bahwasannya penulis melakukan suatu metode untuk penelitian ini menggunakan metode yang sesuai dengan penyusunan jurnal ini. Pendekatan penelitian ini menggunakan studi historis, sedangkan kegiatan pengumpulan data dilakukan dengan teknik wawancara. Hal tersebut tentu sangat relevan dengan judul dan materi yang akan dibahas didalam jurnal ini. Kemudian pada bagian desain penelitian, dalam penelitian ini penulis menggunakan desain penelitian yang berbentuk penelitian kualitatif dimana penelitian ini akan menjelasakan secara teori atau konsep mengenai pendidikan Islam multicultural.

Kemudian mengenai teknik pengumpulan data penulis menggunakan teknik pengumpulkan data yaitu berbetuk wawancara, dimana peneliti mewawancarai salah seorang alumni santri yang pernah mondok dipesantren tersebut, sekaligus sebagai orang yang kritis terhadap pendidikan multikultural dipondok pesantren tersebut. Dan mengumpulkan data dari sumber dan literatur yang ada yang dapat menjadikan acuan dalam penelitian ini yang yang berkaitan dengan masalahmasalah yang dibahas dalam jurnal ini, Baik dari buku maupun jurnal lainnya. Kemudian penulis juga mengumpulkan data dari berbagai sumber lainnya yang dapat membantu dalam mengumpulkan data untuk penelitian ini, seperti mencari informasi dari alumni santri yang pernah mondok dipesantren yang berhubungan dengan msalah jurnal ini. Sehingga sumbersumber tersebut dapat membantu dan dapat dijadikan bahan acuan dalam penulisan jurnal ini.

\section{HASIL DAN PEMBAHASAN}

Dari pemaparan di atas dapat diketahui Mengenai beberapa pondok pesantren yang berdiri di tanah majemuk di Sumatera Utara sebagai miniatur bangsa Indonesia dan khususnya di kabupaten Langkat yang tidak bisa dikatakan mayoritas atau tidak dalam kehidupan berbudaya, kemajemukan dari beberapa suku dan budaya yang ada. Tepatnya di pondok pesantren Ulumul Quran yang setiap pesantren memiliki corak khas dari pendidikan yang diutamakan di dalam menciptakan agent of excellent atau pengkaderan dari santri-santri yang nantinya akan di hasilkan dari pondok pesantren itu, yang dapat menciptkan genarasi santri-santri yang berkualitas dan corak utama pendidikan yang di aplikasikan dalam 
pondok pesantren Ulumul Quran Kecamatan Stabat Kabupaten Langkat adalah bagaimana memiliki santri yang mempunyai pengetahuan teori serta praktek dalam pemahaman dan pengetahuan secara mendalam pada Alquran juga menciptakan hafizh dan Hafidzah, yang memiliki program tersendiri dan program terunggulkan di dalam pesantren ini. dengan adanya pengetahuan teori sekaligus dipraktekkan maka dapat menciptkan santri-santri yang bermutu dan berkualitas Kemudian Bagaimana hasil dari beberapa santri pondok pesantren ulumul Quran yang mengalami proses pendidikan di pondok pesantren ulumul Quran tersebut, mereka menjelaskan bahwa pada dasarnya pondok pesantren Ulumul Quran telah menjalankan suatu proses pendidikan multikultural. Karena mereka telah mengakui adanya perbedaan dari berbagai daerah yang dapat dijadikan suatu pengetahuan bagi setiap masing-masing individu. Karena Pendidikan multikultural ini apabila kita melihat pesantren di beberapa wilayah di pulau Jawa, Pesantren-pesantren besar seperti Pondok Pesantren Krapyak Yogyakarta, pesantren yang berada di Mojokerto, pesantren yang ada di Jombang, pesantren yang ada di beberapa daerah Jawa timur yang mungkin santrinya dari berbagai wilayah Indonesia ataupun mancanegara. Mereka mempunyai ikatan-ikatan santri dari daerah tersebut, contohnya di dalam pondok pesantren
Krapyak Yogyakarta ada sebuah ikatan santri se-jawa timur yang disingkat dengan Insan Sejati dan beberapa himpunan santri Madura atau Himsama. Di dalam corak multikultural secara sosial para santri yang datang di pondok pesantren tidak akan bisa meninggalkan semangat kedaerahan nya, dan bagaimana budaya yang ada di dalam dirinya. Hal ini menumbuhkan seperti untuk kebersatuan lingkup terkecil dan menyusul kepada keberhasilan lingkup terbesar dalam multikulturalisme, akan tetapi hal yang seperti ini juga menjadi bomerang bagi para santri yang terlalu bersemangat dalam mempertahankan semangat kedaerahannya, sehingga mereka lupa bahwa dari semangat kedaerahan untuk menuju pada puncak keberhasilan secara universal. Dan hal ini tidak terjadi di pondok pesantren Ulumul Quran yang berada Langkat walaupun ada santri yang berasal dari Malaysia dan dari berbagai daerah di Indonesia, dari Aceh, Padang, Riau dan lain sebagainya. Pendidikan multikultural ini bukan pendidikan yang tampak pada pola penerapan yang bisa kita lihat secara langsung. Bahwa sejatinya pendidikan multikulturalisme ini masuk ke dalam kurikulum pondok pesantren secara tersirat, dan di pondok pesantren Ulumul Quran memiliki sebuah asrama seperti ciri khas dari pondok pesantren itu sendiri, dan bagaimana penempatan dalam sistem pola pendidikan yang tidak memikirkan dari asal 
daerah, dari latar belakang, suku, aliran agama atau yang lainnya, untuk penyusunan sistem penempatan santri dalam asrama. Dan pola pendidikan di pondok pesantren Ulumul Quran yang mungkin dalam menepis aliran agama yang yang tidak bisa dinafikan, bahwa para santri banyak menganut aliran agama seperti Muhammadiyah, Al Washliyah, Nahdlatul Ulama dan yang lainnya. Pendidikan pesantren terutama pendidikan formal yang teraplikasikan dalam bangku sekolah selayaknya seperti pendidikan biasa, akan tetapi pendidikan multikultural di pondok pesantren Ulumul Quran yakni bagaimana pengamalan-pengamalan suatu pendidikan di bagian non-formal yang teraplikasikan dalam bentuk pembelajaran sore atau tanfidz serta pembelajaran malam mengaji binnadhzar. Ketika santri-santri masih awal dalam memulai pendidiakan, mereka akan di satukan pada santri yang lainnya, dan di bimbing oleh senior yang akan membimbing mereka.

Pola penerapan pendidikan multikulturalisme di dalam pondok pesantren ulumul Quran terletak pada pengamalan kegiatan santri pada shalat berjamaah, beberapa shalat wajib yang diwajibkan untuk memakai baju putih dan kopiah putih, aturan tersebut dibuat oleh Almarhum Almaghfurllah Allahu Yarham Ayahanda Al Mukarom Al-ustadz Buya kyai Haji Rustam Effendi Al Hafidz, semoga
Allah memberikan rahmat ampunan dan tempat terbaik di sisi Allah SWT Amin ya robbal alamin. Bagaimana beliau menerapkan sistem yang sederhana ini, tapi efek dari sistem ini kita tidak membedakan style fashion yang dipakai oleh beberapa santri dari berbagai daerah masing-masing, contohnya kita mengenal topi atau peci Aceh dan peci dari berbagai daerah seperti Padang dan Riau ataupun yang lainnya. Akan tetapi ketika shalat berjamaah, maka tidak ada terlihat lagi identitas dari corak daerah mereka, karena dari pola pemikiran aturan tersebut bahwa kita beribadah kepada Allah tak membedakan suku, ras, bahasa dan aliran agama apapun yang mempunyai ciri khas tersendiri dalam tampilan atau pengamalan ibadah. Ciri khas yang tepat dikatakan pendidikan multikultural dalam pendidikan nonformal yang ada di pondok pesantren Ulumul Quran yang paling tepat dalam mengatur pengakulturasian dan bentuk afirmasi dari pendidikan multikultural yang bahkan berhasil diterapkan adalah pengamalan aturan shalat berjamaah ini. sehingga pendidikan multikultural dipondok pesantren ulumul qur'an ini dapat dijalankan dengan lancer tanpa membeda-bedakan budaya antara yang satu dengan yang lainnya. Gunaknya agar setiap individu dapat saling mengenal budaya yang dimiliki oleh setiap individu.

Di dalam Jurnal yang di tulis oleh Suheri dan Yeni Tri Rahmawati dengan 
sebuah judul "Model Pendidikan Multikultural Di Pondok pesantren". Pada hasil penelitian yang di lakukan beberapa temuan setidaknya ada empat poin yaitu, bagaimana konsep pendidikan multikulturaslisme, sistem nilai pesantren, solidaritas keadilan sosial, dan Relasi gender.

Secara konsep pendidikan di temukan bahwa para santri ketika telah berada di dalam pondok tersebut, dengan satu tujuan yakni menuntut ilmu dan pengharapan keridhaan Allah SWT, maka segala jenis atribut material ataupun non material seperti suku, ras, budaya dan lain sebaginya, akan terlepas dalam artian tidak menjadi ghirah dan tujuannya, maka dengan sendirinya akan terkikis oleh interaksi sosial yang lebih dalam. Kemudian implementasi konsep multikulturalisme dilakukan dengan merujuk pada teks agama (religius multiculturalism), dan ukhuwah yang di bangun di dalam konsep ini yaitu berupa relasi apabila tidak satu agama (ukhuwah islamiyah), memahami dan berada pada relasi satu ideologi negara (ukhuwah wathamiyah), biila tidak satu negara mereka masih dalam satu kerangka dalam bangsa manusia (ukhuwah basyariyah).

Hasil riset di pesantren Kauman Alhasani Allathifi adalah sikap yang memandang sebuah kehidupan adalah suatu rangkaian keseluruhan dalam konteks beribadah kepada Allah SWT, bukan hanya ibadah madhah akan tetapi ibadag ghairu madhah yang terimplemetasi dengan sendirinya oleh kultur pesantren itu. Kemudian bagaimana solidaritas dan keadilan sosial tercerminkan di dalam pondok tersebut yakni, ketika setelah shalat berjamaah ashar, para santri makan secara bersama dalam sebuah wadah nampan besar, dari ciri khas pesantren itu sendiri yang dapat memunculkan suatu pengoptimalan dalam penanaman jiwa pesantren tersebut.

Dalam suatu relasi gender yang di bangun pada umumnya setiap pesantren mengetatkan dalam pertemuan pada ajnabih atau juga santri putra dan putri untuk berinteraksi secara intens apalagi berkhalwat, akan tetapi relasi ini bahkan memberikan suatu pola pemikiran ataupun paradigma bagaimana penghargaan kita terhadap lawan jenis terkhusus pada wanita teramat sangat di pelihara dan di agungkan.(Suheri \& Nurrahmawati, 2018)

Dalam jurnal yang di tulis oleh Saiful Amin Ghofur yang berjudul "Membumikan Pendidikan Multikultural Di Pesantren” yang demikian merupakan hasil dari review sebuah buku tulisan Dr. Abdullah Aly, M.Ag yang berjudul "Pendidikan Islam Multikultural Di Pesantren (Telaah terbdap Kurikulum Pondok. Pesantren Modern Assalam Surakarta). Beliau menggambarkan sebuah realitas multikultural dalam pondok pesantren, Dalam pandangan sosiologis bagaimana kemajemukan yang datang akan sirna 
dengan sendirinya oleh mesin konstruksi budaya lokas dalam pesantren itu. Suku, ras, budaya, bahasa dan adat istiadat akan melebur dengan sebuah kontstruksi peradaban dan pola pendidikan multikultural di pesantren tersebut.(Ghofur, 2011)

Modal sosial dan kultur yang dibawa oleh para santri ini lah yang nantinya dapat di lunakan dengan berkomunikasi secara sinergis. Di pesantren identitas kedaerahan bukanlah sirna begitu saja, tetapi tetap kentara. Maka tidak sedikit jika di pesantren muncul suatu kelompok berbasis etnis kedaerahan dengan bersandar pada semangat promordialitas.

\section{SIMPULAN}

Pondok pesantren Ulumul Qur'an ini terletak di kec. Stabat Kab. Langkat Sumatera Utara. Dimana pondok pesantren ini pada prosesnya telah menerapkan proses pendidikan multikultural didalamnya. Dalam penelitian ini membahas tentang bagaimana pendidikan Islam multikultural dipondok pesantren Ulumu Qur'an yang dilakukan pada santri-santri yang memiliki keragaman budaya yang dapat dijadikan suatu pengetahuan yang luas demi menciptakan persatuan dan kesatuan bangsa maupun Negara.

Pendidikan multicultural lahir diakibatkan adanya permasalahan manusia yang ditindas karena adanya perbedaan satu sama lain. Karena Pendidikan multicultural itu sangat penting untuk memandang bahwa semua manusia itu setara, tidak adanya perbedaan, dapat bekerja sama, saling menghormati dan menghargai walaupun terdapat perbedaan. Dalam perspektif islam keragaman tersebut justru merupakan sunnatullah atau kehendak tuhan yang dijelaskan dalam al Qur'an QS Hud ayat 118 dan Arrum ayat 22, yang sengaja diciptakan sebagai sarana untuk saling mengenal anatara yang satu dengan yang lain. yang tercantum dalam QS Al-Hujurat ayat 13. Dengan demikian Islam secara tegas menghendaki dan menganggap realitas multikultural bukan sebagai problem melainkan sebagai asset yang bisa didayagunakan baik dalam konteks hubungan social maupun dalam relasi kemanusiaan yang lebih luas.

Pesantren Ulumul Quran telah menjalankan sebuah proses pendidikan multikultural. Pengaplikasian pendidikan multikultural di dalam pondok pesantren yakni tidak mebeda-bedakan budaya yang dimiliki oleh masing-masing santri yang ada dipondok pesantren ulumul qur'an tersebut. Bahkan pendidikan multikultural ini masuk kedalam kurikulum pondok pesantren tersebut. Di dalam corak multikultural secara individu sosial para santri yang datang di pondok pesantren tidak akan dapat sepenuhnya meninggalkan semangat kedaerahan nya, dan bagaimana budaya yang ada di dalam karakter dirinya. Hal ini menumbuhkan seperti semangat sosial 
kebersatuan lingkup terkecil dan menyusul kepada keberhasilan suatu sosial pada lingkup terbesar dalam multikulturalisme.

Kemudian pola pendidikan di pondok pesantren Ulumul Quran yang mungkin dalam menepis aliran agama yang yang tidak bisa dinafikan, bahwa para santri banyak menganut aliran agama seperti Muhammadiyah, Al Washliyah, Nahdlatul ulama dan yang lainnya. Dimana pendidikan multikultural di pondok pesantren Ulumul Quran bagaimana pengamalan-pengamalan pendidikan dibagian non-formal yang teraplikasikan dalam bentuk pembelajaran sore atau tanfidz serta pembelajaran malam mengaji binnadhzar. Pola penerapan pendidikan multikulturalisme di dalam pondok pesantren ulumul Quran terletak pada pengamalan kegiatan santri pada shalat berjamaah beberapa salat wajib yang diwajibkan untuk memakai baju putih dan kopiah putih, aturan tersebut dibuat oleh Almarhum Almaghfurllah Allahu Yarham Ayahanda Al Mukarom Al-ustadz Buya kyai Haji Rustam Effendi Al Hafidz. beliau menerapkan sistem yang sederhana ini, mrmpunyai efek dari sistem ini yaitu kita tidak membedakan style fashion yang dipakai oleh beberapa santri dari berbagai daerah masing-masing. Kerena dengan adanya system sederhana yang diterapkan dipondok pesantren ulumul qur'an ini dapat memberikan pengetahuan laus tentang budaya dan pendidikan multikultural yang dimiliki oleh setiap individu.

\section{DAFTAR PUSTAKA}

Abdullah, J. (2018). Pendidikan Islam Multikultural di Pesantren (Studi Kasus Pada Pondok Pesantren Sirojul Ulum Semanding Pare Kediri). Inovatif: Jurnal Penelitian Pendidikan, Agama Dan Kebudayaan, 4(1), 83-84. http://jurnal.staih.ac.id/index.php/ino vatif/article/view/66

Badri Khairuman. (2004). Moralitas Islam. pustaka setia.

Dani Nurcholis. (2019). Transformasi Pendidikan Multikultural Di Sekolah (Mudjito \& Naufi (ed.)). CV. Parasurama Education.

Darmaningtyas. (2004). Pendidikan yang Memiskinkan (I. G. \& S. Dema (ed.)). Galang press.

Ghofur, S. A. (2011). Membumikan Pendidikan Multikultural Di Pesantren. Millah, 11(1), 291-301. https://doi.org/10.20885/millah.vol11 iss1.art15

Goyena, R., \& Fallis, A. . (2019). 済無No Title No Title. Journal of Chemical Information and Modeling, 53(9), 16891699.

https://doi.org/10.1017/CBO9781107 415324.004

Murniati Agustian. (2019). pendidikan multikultural (universitas katolik indonesia atama jaya (ed.)).

Mustaghfiroh, H., Islam, U., Fatah, S., \& Tengah, J. (2013). Pendidikan Islam Berbasis Manusia Yang Sempurna (Insan Kamil ) Harus Mampu Mengelola. 7(1), 105-128.

Rois, A. (2013). Pendidikan Islam Multikultural: Telaah Pemikiran Muhammad Amin Abdullah. Epistemé: Jurnal Pengembangan Ilmu Keislaman, 8(2), 305-306. https://doi.org/10.21274/epis.2013.8. 2.301-322 
Samsul Mu'arif. (2005). Pendididikan Multikulturalisme Di Indonesia. Logung Pustaka.

Sauqi Futaki. (2019). Kapital Multikultural Pesantren (cet. I). Deepublish.

Sonia Nieto. (2002). culture and theaching. laurence earlbaum.

Suheri, \& Nurrahmawati, Y. T. (2018). Model Pendidikan Multikultural di Pondok Pesantren. Al-Insyiroh: Jurnal Studi Keislaman, 05(1), 297-298. https://doi.org/10.35309/alinsyiroh.v $2 \mathrm{i} 1.3332$

Zakiyuddin Baldhawi. (2005). pendidikan agama berwawasan multikultural (S. Mahdi (ed.)). Erlangga. 